\title{
Increasing Medicinal and Phytochemical Compounds of Coneflower (Echinacea Purpurea L.) Medicinal Plant using New Hydroponic Culture Media and Nutrition Pattern
}

\author{
Fatemeh Ahmadi \\ Urmia University \\ Abbas Samadi ( $\nabla$ soilscience2017@gmail.com ) \\ Urmia University \\ Ebrahim Sepehr \\ Urmia University \\ Amir Rahimi \\ Urmia University \\ Sergey Shabala \\ University of Tasmania
}

\section{Research Article}

Keywords: Ammonium and nitrate, Alkylamides, Caffeic acid, Echinacea purpurea, Perlite size

Posted Date: April 27th, 2021

DOI: https://doi.org/10.21203/rs.3.rs-452779/v1

License: (c) (i) This work is licensed under a Creative Commons Attribution 4.0 International License.

Read Full License

Version of Record: A version of this preprint was published at Scientific Reports on July 26th, 2021. See the published version at https://doi.org/10.1038/s41598-021-94589-4. 


\title{
Increasing medicinal and phytochemical compounds of coneflower (Echinacea
}

purpurea L.) medicinal plant using new hydroponic culture media and nutrition pattern

\author{
Fatemeh Ahmadi $^{1,3}$, Abbas Samadi ${ }^{*}$, Ebrahim Sepehr ${ }^{1}$, Amir Rahimi $^{2} \&$ Sergey Shabala ${ }^{3}$ \\ ${ }^{1}$ Department of Soil Science, Faculty of Agriculture, Urmia University, Urmia, Iran \\ ${ }^{2}$ Department of Plant Production and Genetics, Faculty of Agriculture, Urmia University, Urmia, Iran \\ ${ }^{3}$ Tasmanian Institute of Agriculture, University of Tasmania, Hobart, Tasmania 7001, Australia \\ "Corresponding author; E-mail: a.samadi@urmia.ac.ir
}

Medicinal plants are considered as one of the most important sources of chemical compounds, so preparing a suitable culture media for medicinal plant growth is a critical factor. The present study is aimed to improve the caffeic acid derivatives and alkylamides percentages of Echinacea purpurea root extract by optimizing the $\mathrm{NO}_{3}-\mathrm{NH}_{4}{ }^{+}$ratio in new hydroponic culture media. Perlite particle size in the growing media was varied as very coarse perlite (more than $2 \mathrm{~mm}$ ), coarse perlite $(1.5-2 \mathrm{~mm})$, medium perlite (1-1.5 mm), fine perlite $(0.5-1 \mathrm{~mm})$, and very fine perlite (less than $0.5 \mathrm{~mm}$ ) with a mixture of peat moss at $50: 50 \mathrm{v} / \mathrm{v}$ and 30:70 v/v peat moss to perlite ratios. Two $\mathrm{NO}_{3}{ }^{-} / \mathrm{NH}_{4}{ }^{+}$ratios $(90: 10$ and 70:30) were tested in each growing media. All phytochemical analyses were performed according to standard methods using high performance liquid chromatography (HPLC). It was found that the $E$. purpurea grown in the medium containing very fine-grade perlite with 50:50 v/v perlite to peat moss ratio had the maximum caffeic acid derivatives, including chicoric acid (17 mg/g DW), caftaric acid $(6.3 \mathrm{mg} / \mathrm{g}$ DW), chlorogenic acid $(0.93 \mathrm{mg} / \mathrm{g}$ DW), cynarin $(0.84$ $\mathrm{mg} / \mathrm{g} \mathrm{DW})$, and echinacoside $(0.73 \mathrm{mg} / \mathrm{g} \mathrm{DW})$, as well as, alkylamides $(54.21 \%)$. The percentages of these phytochemical compounds increased by decreasing perlite particle size and increasing of $\mathrm{NO}_{3}{ }^{-} / \mathrm{NH}_{4}{ }^{+}$ratio. The major alkylamide in the $E$. purpurea root extract was dodeca-2E, 4E, 8Z- $10(\mathrm{E} / \mathrm{Z})$-tetraenoic acid isobutylamide in all treatments, ranging from $31.12 \%$ to $54.21 \%$ of total dry weight. It can be concluded that optimizing hydroponic culture media and nutrient solution has significant effects on $E$. purpurea chemical compounds.

Keywords: Ammonium and nitrate, Alkylamides, Caffeic acid, Echinacea purpurea, Perlite size 
The Echinacea purpurea, widely known as purple coneflower, is one of the popular medicinal plants of the Asteraceae family, from United States, Canada, Russia, and Australia. In recent years, it has gained international popularity due to claims that it beneficially stimulates the body's immune system ${ }^{4,20}$. Extracts from the plant have shown antioxidative, antibacterial, antiviral, and antifungal properties, and are used in the treatment of the common cold, as well as respiratory and urinary diseases ${ }^{11,35}$. Caffeic acid derivatives, namely caftaric acid, chlorogenic acid, cynarin, echinacoside, and cichoric acid, are the main compounds of Echinacea spp. Of the caffeic acid derivatives, cichoric acid has been shown to possess immunostimulatory properties, promoting phagocyte activity both in vitro and in vivo. Besides, cichoric acid has exhibited antihyaluronidase activity, and a protective effect on the free radical-induced degradation of collagen. Cichoric acid has also been shown to have antiviral activity ${ }^{9,14}$ and, recently, inhibit HIV1 integrase and replication ${ }^{8,34}$. Echinacoside does not contribute towards the immunostimulant activity, but prospects collagen against reactive oxygen species, and also has antioxidant ${ }^{12}$, antiinflammatory, and cicatrizing activities ${ }^{30}$. Caftaric acid and chlorogenic acid play an important role in antiviral activity ${ }^{37}$, an effective free radical scavenging agent and preserver of collagen from free radical-induced degradation ${ }^{30}$. Therefore, caffeic acid derivatives are widely measured as markers to determine the medicinal quality of E. purpurea extracts ${ }^{16}$. The alkylamides, as a group of bioactive compound, has attached the most interest in terms of pharmacological activity ${ }^{23}$. Plants containing alkylamides are used as spices for their pungent and tingling sensations and are incorporated into topical cosmetics for their wrinkle-smoothing and anti-aging properties ${ }^{15}$. There is increasing evidence that lipophilic Echinacea preparations containing $\mathrm{N}$-alkylamides can suppress stress-related cellular immune responses ${ }^{28}$. It was also demonstrated recently in several studies that alkylamides -containing Echinacea preparations trigger effects on the proinflammatory cytokines ${ }^{17}$. Thus, it seems necessary to pay attention to effective strategies to improve the quality of $E$. purpurea phytochemical compounds.

Different cultivation strategies have been developed for the production of E. purpurea. However, there are many considerations for plant production in greenhouse conditions, especially in hydroponic (or soilless) culture systems in recent years ${ }^{27}$. Growing in hydroponic media may offer several advantages over field cultivation by controlling the plant nutrition requirement and facilitating the growth conditions ${ }^{13,32}$. Meanwhile, using artificial substrates in the hydroponic cultivation system reduce the cost of establishing advanced cultivation systems, and it enables the farmer to make practical use of it by using commonly raw materials such as cocopeat, sand, and vermiculite as an initial plant growing media ${ }^{9,31}$. Nevertheless, different inorganic and organic products such as peat moss, perlite, mixed materials, etc., are fully or partially used instead of initial substrates due to their useful physical properties ${ }^{31}$. The particle size of substrates is a critical factor in air and water-holding capacity, root distribution, and plant growth, which are different based on their origin and preparation conditions ${ }^{8,18}$. A high volume of roots can concentrate at the top portion of the container includes low aeration and high water-holding capacity ${ }^{31}$. 
Attention to the chemical quality of hydroponic nutrient solution and its effect on yield and active compounds is so important ${ }^{1}$. Of these nutrients, two major inorganic forms of nitrogen $(\mathrm{N})$, the ammonium $\left(\mathrm{NH}_{4}{ }^{+}\right)$and the nitrate $\left(\mathrm{NO}_{3}{ }^{-}\right)$, can differentially impact plant growth in many plant species ${ }^{40}$. Although the assimilation and metabolism of $\mathrm{NH}_{4}{ }^{+}$form require less energy than that of $\mathrm{NO}_{3}{ }^{-}$in plants, the majority of plant species grow better on $\mathrm{NO}_{3}{ }^{-}$since $\mathrm{NH}_{4}{ }^{+}$is toxic for plants and a few species grow well if $\mathrm{NH}_{4}{ }^{+}$is the only source of $\mathrm{N}$. It has been reported that using a mixture of $\mathrm{NO}_{3}{ }^{-}$and $\mathrm{NH}_{4}{ }^{+}$is optimum for nitrogen nutrient in most of the $\mathrm{crops}^{40}$. Previous research demonstrated that the $\mathrm{NO}_{3}{ }^{-} / \mathrm{NH}_{4}{ }^{+}$ratio could affect the morphological properties of E. purpurea 3,13. Zheng et al (2006) and Ahmadi et al (2021) reported that increasing $\mathrm{NO}_{3}{ }^{-}$concentration in nutrient solution increased total phenolic and flavonoid contents of E. purpurea root extract. However, the plant species and environmental conditions are two critical factors that affect the optimum $\mathrm{NO}_{3}{ }^{-} / \mathrm{NH}_{4}{ }^{+}$ratio ${ }^{22}$. So, the present research is focused on the development a new hydroponic culture media with various perlite particle sizes and different $\mathrm{NO}_{3}{ }^{-} / \mathrm{NH}_{4}{ }^{+}$ratios for improving the caffeic acid derivatives and alkylamides compounds of $E$. purpurea root extract at greenhouse conditions.

\section{Material and methods}

Growing conditions. The experiment was accomplished in the research greenhouse at Urmia University, Iran. The plant growth conditions were controlled regularly inside the greenhouse (temperature, humidity, and photosynthetic photon flux density (PPFD) were $22 / 18{ }^{\circ} \mathrm{C}$ (day/night), $70 \%$, and $650 \mu \mathrm{mol} \mathrm{m}^{-2} \mathrm{~s}^{-1}$ respectively). The E. Purpurea Seeds were purchased from an Iranian private joint-stock company, Pakan Bazr Esfahan (www. Pakanbazr.com). The seeds were sowed in plastic cups filled with a mixture of perlite and peat mass substrates as a medium to initiate germination. Irrigation was performed based on greenhouse conditions regularly. Seedlings (with four real leaves) were translocated to experimental plastic pots $(2.5 \mathrm{~L})$ containing a different ratios of perlite and peat mass as artificial substrates $(100 \%$ perlite, $100 \%$ peat moss, $50 \%$ (v) perlite + $50 \%$ (v) peat moss, $70 \%(\mathrm{v})$ perlite $+30 \%$ (v) peat moss) with various perlite particle size containing less than $0.5 \mathrm{~mm}, 0.5-1 \mathrm{~mm}, 1-1.5 \mathrm{~mm}, 1.5-2 \mathrm{~mm}$, and more than $2 \mathrm{~mm}$. The chemical composition of the nutrient solution is shown in Table 1. The $\mathrm{pH}$ and electrical conductivity (EC) of the nutrient solution were maintained between 5.7 to 6.2 and 1.0 to $1.5 \mathrm{dS} \mathrm{m}^{-1}$, respectively. According to the plant growth stage, 0.5 to $3.5 \mathrm{~L} \mathrm{day}^{-1}$ was used in irrigation system ${ }^{40}$. The E.purpurea grown at different culture media at the flowering stage were shown in Figure 1. 


\begin{tabular}{|l|l|c|}
\hline Element & Fertilizer type & Attribute \\
\hline $\mathrm{N}(\mathrm{mM})$ & $\left(\mathrm{NH}_{4}\right)_{2} \mathrm{SO}_{4}-\mathrm{KNO}_{3}-\mathrm{Ca}\left(\mathrm{NO}_{3}\right)_{2}$ & 15 \\
\hline $\mathrm{P}(\mathrm{mM})$ & $\mathrm{H}_{3} \mathrm{PO}_{3}$ & 1 \\
\hline $\mathrm{K}(\mathrm{mM})$ & $\mathrm{KNO}_{3}$ & 6 \\
\hline $\mathrm{Ca}(\mathrm{mM})$ & $\mathrm{Ca}\left(\mathrm{NO}_{3}\right)_{2}$ & 4 \\
\hline $\mathrm{Mg}(\mathrm{mM})$ & $\mathrm{MgSO}_{4} \cdot 7 \mathrm{H}_{2} \mathrm{O}$ & 2 \\
\hline $\mathrm{S}(\mathrm{mM})$ & Sulfate fertilizers & 2 \\
\hline $\mathrm{Fe}(\mu \mathrm{M})$ & $\mathrm{Fe}-\mathrm{EDTA}$ & 50 \\
\hline $\mathrm{Mn}(\mu \mathrm{M})$ & $\mathrm{Mn} \mathrm{SO} 4 \cdot \mathrm{H}_{2} \mathrm{O}$ & 9 \\
\hline $\mathrm{Cu}(\mu \mathrm{M})$ & $\mathrm{CuSO}{ }_{4} 5 \mathrm{H}_{2} \mathrm{O}$ & 0.3 \\
\hline $\mathrm{Zn}(\mu \mathrm{M})$ & $\mathrm{ZnSO}_{4} \cdot 7 \mathrm{H}_{2} \mathrm{O}$ & 0.8 \\
\hline $\mathrm{B}(\mu \mathrm{M})$ & $\mathrm{H}_{3} \mathrm{BO}_{3}$ & 15 \\
\hline $\mathrm{Mo}(\mu \mathrm{M})$ & $\mathrm{H}_{24} \mathrm{Mo}_{7} \mathrm{~N}_{6} \mathrm{O}_{24 \cdot 4} \mathrm{H}_{2} \mathrm{O}$ & 0.11 \\
\hline
\end{tabular}

Table 1. Chemical properties of nutrient solution.
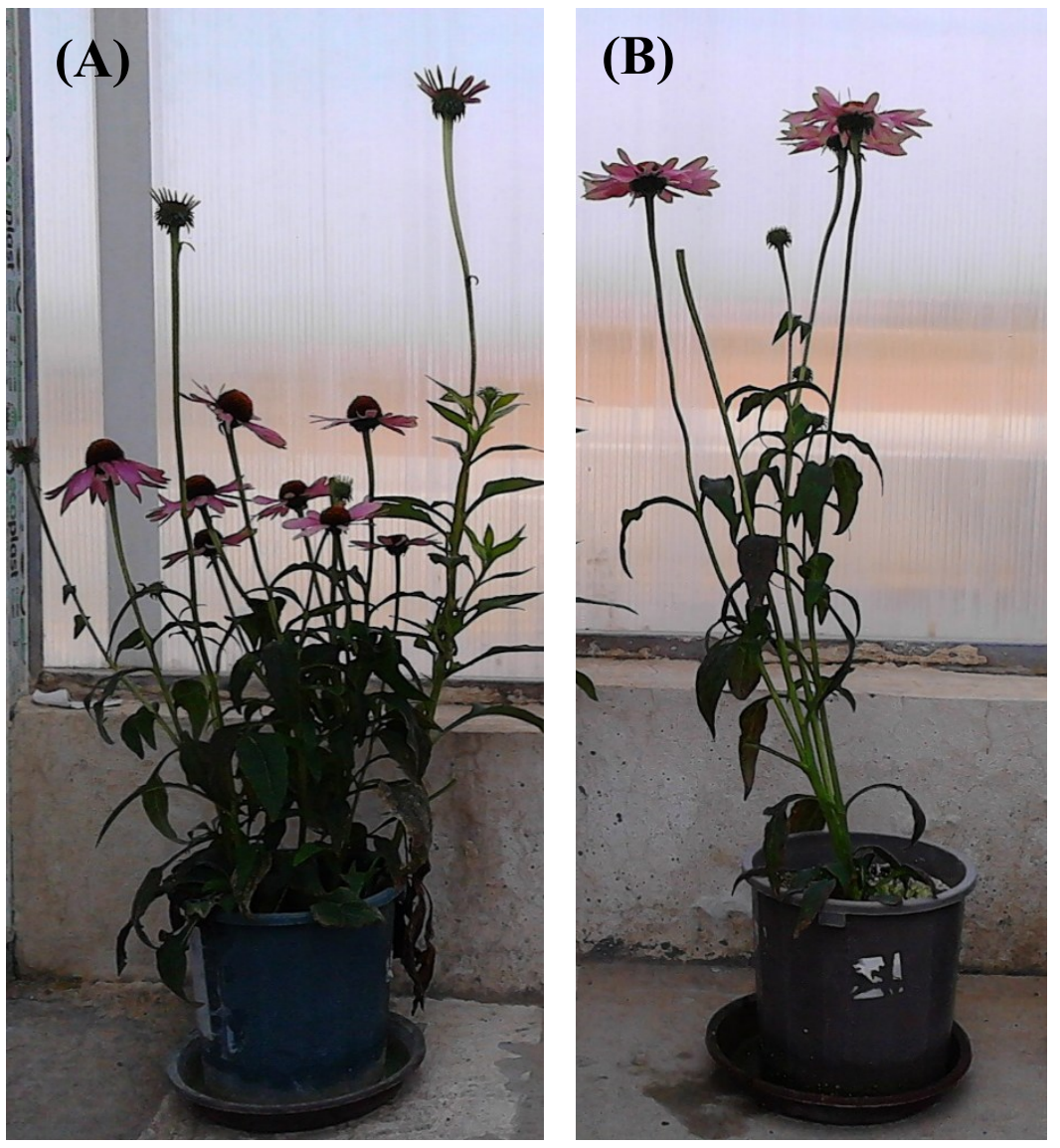

(C)

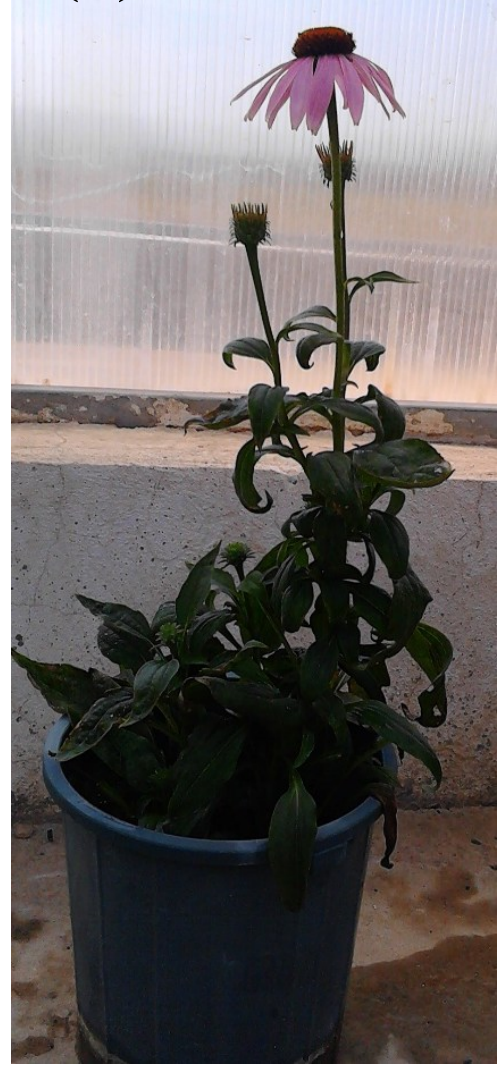




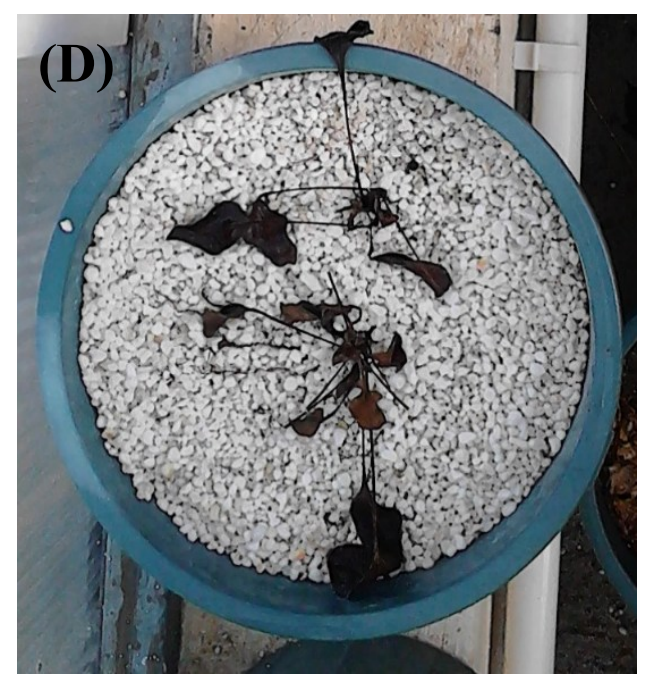

Fig. 1. Echinacea purpurea grown in (A) $50 \%$ peat moss $+50 \%$ perlite $(<0.5 \mathrm{~mm})$, (B) $30 \%$ peat moss + $70 \%$ perlite $(<0.5 \mathrm{~mm}),(\mathrm{C}) 100 \%$ peat moss, and (D) $100 \%$ perlite $(>2 \mathrm{~mm})$ culture media, just at $90: 10$ $\mathrm{NO}_{3}{ }^{-} / \mathrm{NH}_{4}{ }^{+}$ratio (All photos were taken by $\mathrm{F}$. Ahmadi).

Sample preparation. Plants were harvested at the end of the flowering stage (eight months). The plants were divided into roots, stems, flower heads, and lower and upper leaves after washing with tap water. Root, samples were dried at $25 \pm 1^{\circ} \mathrm{C}$, ground into a fine powder, and collected for phytochemical analysis ${ }^{6}$.

Total phenolic content. Measuring the total phenolic compounds in root samples was performed by the Folin- Ciocalteau method adapted from Singleton et al (1999). In details, $10 \mu \mathrm{L}$ of methanolic extracts and $1600 \mu \mathrm{L}$ of distilled water was mixed, then $200 \mu \mathrm{L}$ of Folin-Ciocalteau reagent $\left(10 \% \mathrm{~V} / \mathrm{V}\right.$ prepared in distilled water) were added and left at $25^{\circ} \mathrm{C}$ for $5 \mathrm{~min}$, then $200 \mu \mathrm{L}$ of sodium carbonate $(7.5 \%)$ was added and left in a dark place at $25^{\circ} \mathrm{C}$ for $30 \mathrm{~min}$. The absorbance was measured at $760 \mathrm{~nm}$ using a spectrophotometer (UV-Visible Spectrophotometer, USA). To quantitative analysis of total phenolic content, the gallic acid was used as an external standard, and total phenolic content was expressed as $\mathrm{mg}$ gallic acid $\mathrm{g}^{-1} \mathrm{DW}^{33}$.

Caffeic acid derivatives. The phenolic acids analysis was carried out on an Agilent Technologies 1100 series HPLC (Agilent Technologies, Wilmington, DE, USA), equipped with a $20 \mu \mathrm{L}$ manual sample loop, degasser, quaternary pump, column oven, and diode array detector. The Separation of analytes was performed on the ZORBAX Eclipse XDB column $(4.6 \mathrm{~mm} \times 250 \mathrm{~mm}, 5 \mu \mathrm{m}$ pore size, Germany), which was thermostatically controlled at $28^{\circ} \mathrm{C}$ according to a method adapted from Mei et al (2020). The extracts were filtered (through a $0.45 \mu \mathrm{m}$ filter), and then $20 \mu \mathrm{L}$ was injected into the HPLC-DAD. A gradient elution program was used to separation of phenolic acids, by changing the acetonitrile to the acetic acid proportion $(1.0 \% \mathrm{~V} / \mathrm{V}$ in water). The initial composition of the mobile phase was acetonitrile and acetic acid $(1.0 \% \mathrm{~V} / \mathrm{V}$ in water) with a 10:90 portion. Then, the composition of the mobile phase was changed from $10 \%$ to $25 \%$ acetonitrile for $5 \mathrm{~min}$, from 25 to $65 \%$ acetonitrile in $10 \mathrm{~min}$, and remained in this condition for $5 \mathrm{~min}$. After that, the 
mobile phase composition back to the initial condition for $5 \mathrm{~min}$ and kept for another $5 \mathrm{~min}$, before the injection of another sample. The total time of analysis per sample was $30 \mathrm{~min}$. The flow rate was adjusted at $1.5 \mathrm{~mL} \mathrm{~min}^{-1}$, and the wavelengths of detection of phenolic acids and recording of chromatograms were set at 272, 250,310, and $360 \mathrm{~nm}$. Identification of the phenolic compounds was based on comparing the retention time and diode array spectra of commercially standard compounds with components of real samples. Stock standard solutions of phenolic acids (1000 $\mu \mathrm{g}$ $\mathrm{mL}^{-1}$ ) were prepared by dissolving $10 \mathrm{mg}$ of each analyte in $10 \mathrm{~mL}$ liquid chromatographic grade methanol followed by sonication for $10 \mathrm{~min}$, placed in dark-brown vials, and stored in a refrigerator at $4^{\circ} \mathrm{C}$. The content of each phenolic acid in the sample was calculated using the calibration curves equation and the integrated peak area. The HPLC profile of a standard mixture of caffeic acid derivatives is shown in Figure 2.

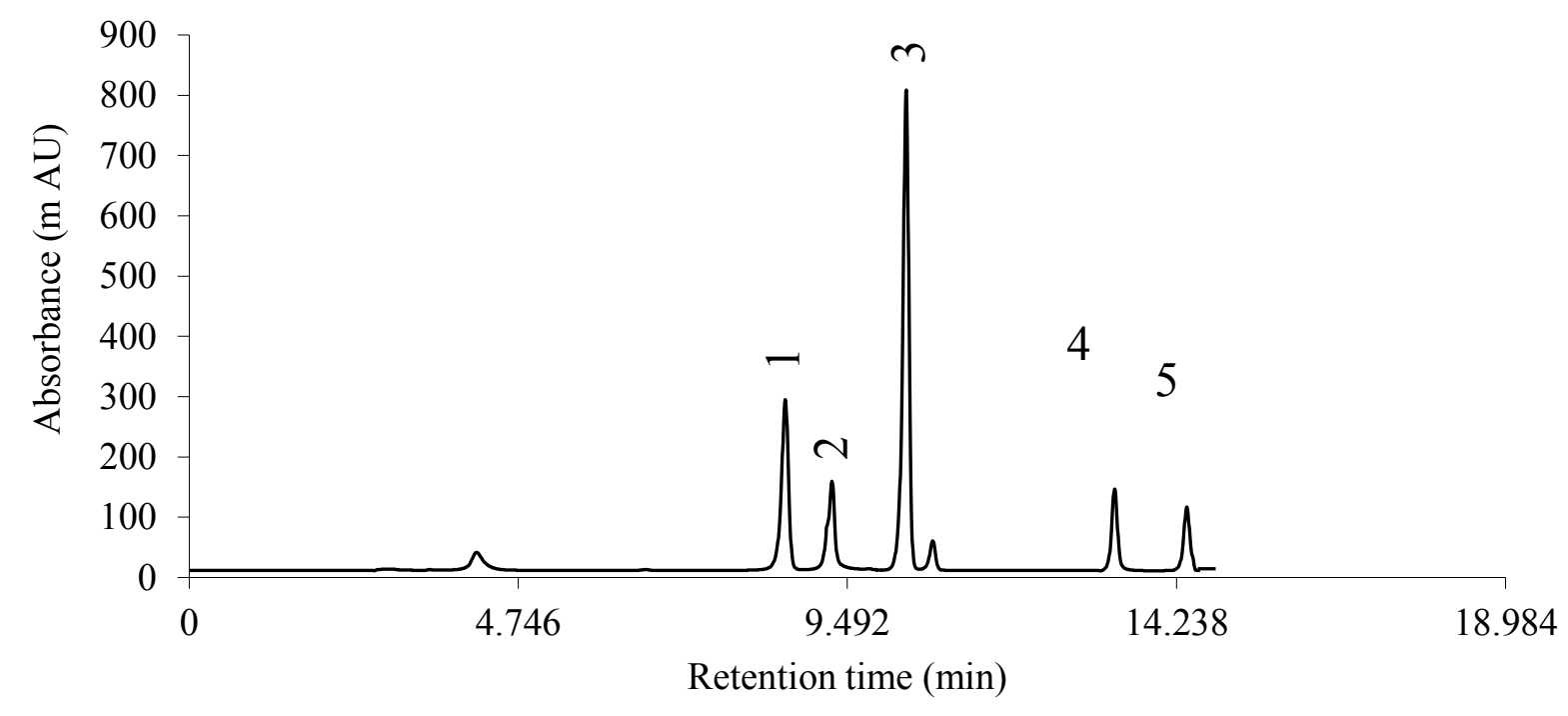

Fig. 2. HPLC profile of a standard mixture of caffeic acid derivatives. Peak 1, caftaric acid; 2, chlorogenic acid; 3 , chicoric acid; 4 cynarin, and 5 , echinacoside.

Alkylamides. A sub-sample ( $1 \mathrm{~g})$ was mixed with $100 \%$ methanol for the alkylamides and the mixture sonicated for ten minutes, filtered through Whatman \#1 paper, and the liquid extract made up to $100 \mathrm{~mL}$. Considerable effort was devoted to maximizing the amount of constituents extracted ${ }^{15}$. Aliquots $(20 \mu \mathrm{L})$ were analyzed by HPLC as described. The mobile phase for alkylamide separation was modified from Bauer and Remiger (1989) and utilized an acetonitrile/water gradient commencing at $40 \%$ acetonitrile for $10 \mathrm{~min}$ followed by a gradient ramp at $1 \mathrm{~mL} / \mathrm{min}$ to $53 \%$ acetonitrile at $35 \mathrm{~min}$ ). The mobile phase for caffeoyl phenol separation was modified from Bauer (4) and utilized an acidified ( $1 \%$ of $\left.0.1 \mathrm{M} \mathrm{H}_{3} \mathrm{PO}_{4}\right)$ methanol/water gradient commencing at $10 \%$ methanol gradient ramp at $1 \mathrm{~mL} \mathrm{~min}^{-1}$ to $50 \%$ methanol at $20 \mathrm{~min}$. Quantification was based on the peak area of working reference compounds. The alkylamide working reference compound was trans, trans-2, 4-dodecadienal (Lancaster Synthesis, Eastgate, England), which was initially 
calibrated against an isomeric mixture dodeca-2, 4, 8, 10-tetraenoic acid isobutyl amide. The alkylamides were quantified using the same response factor for all peaks.

Statistical Analysis. The statistics were based on the factorial with a completely randomized design with three replications. The factors contained different sizes of perlite, including very coarse perlite (more than $2 \mathrm{~mm})$, coarse perlite $(1.5-2 \mathrm{~mm})$, medium perlite $(1-1.5 \mathrm{~mm})$, fine perlite $(0.5-1 \mathrm{~mm})$, and very fine perlite (less than $0.5 \mathrm{~mm})$, two $\mathrm{NO}_{3}{ }^{-} / \mathrm{NH}_{4}{ }^{+}$rations (90:10 and 70:30), and a mixture of peat moss with different size of perlite at 50:50 v/v and 30:70 v/v peat moss to perlite ratios and pure peat moss $(100 \%$ by volume). Data were analyzed using Duncan's multiple range tests at $P \leq$ 0.01, using SAS (Version 9.4; SAS Institute, 2011) statistical program.

License for the collection of plant specimen. The authors declare that the collection of plant and seed specimens were according to authorized rules.

Complying with relevant institutional, national, and international guidelines and legislation. The authors declare that all relevant institutional, national, and international guidelines and legislation were respected.

\section{Results and Discussion}

Phenolic compounds and Caffeic acid derivatives. Medicinal herbs are often cultivated in soilless cultures, and the quality of phytochemical compounds is strongly affected by the nutrient solution ${ }^{2}$. Results of total phenolics content and caffeic acid derivatives in root samples of E. purpurea subjected to different $\mathrm{NO}_{3}{ }^{-} / \mathrm{NH}_{4}{ }^{+}$ratios are shown in Figures 3 and 4, respectively.

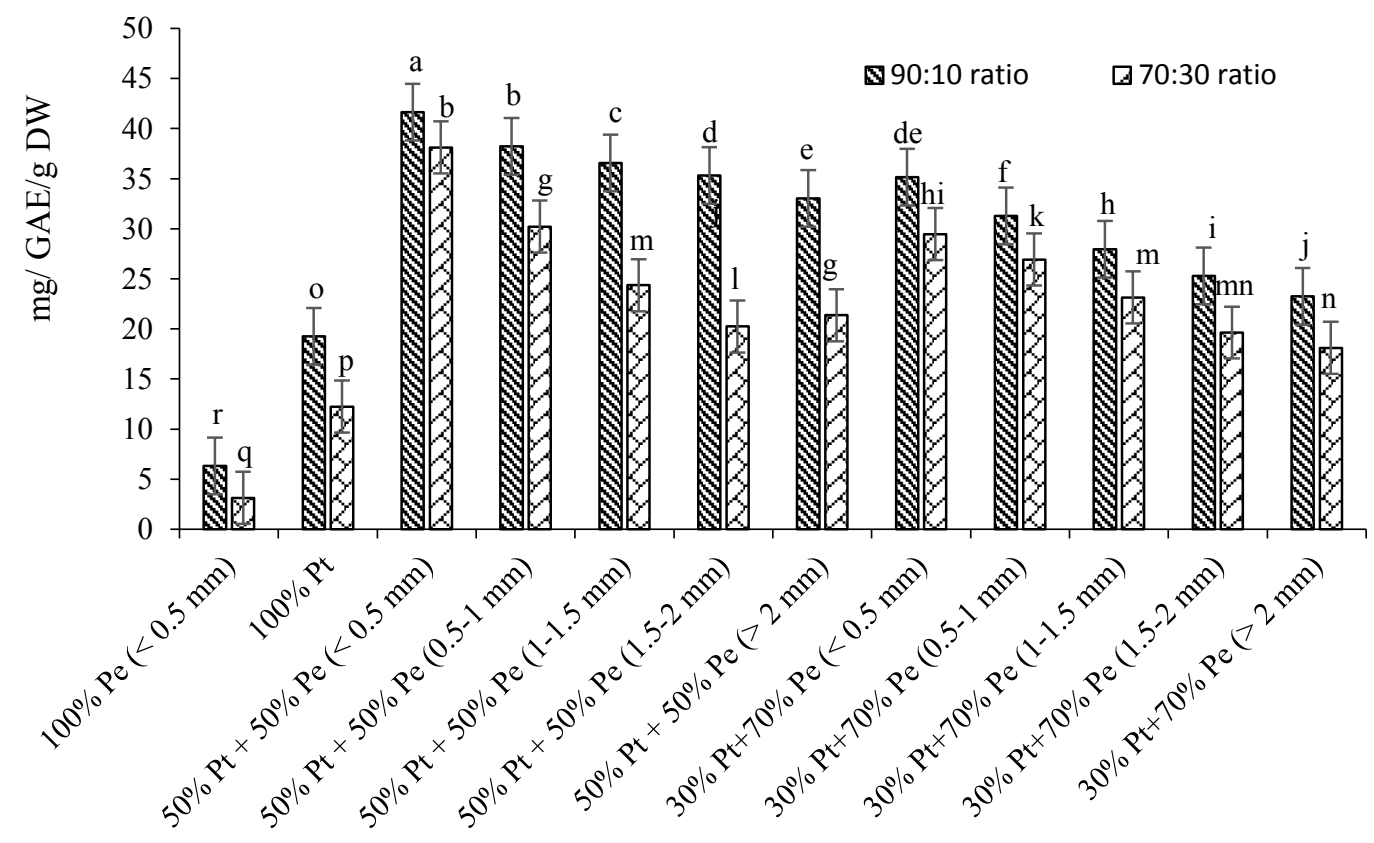

Culture media

Fig. 3. Total phenolic of E.purpurea root at different culture media and $\mathrm{NO}_{3}{ }^{-} \mathrm{NH}_{4}{ }^{+}$ratio. 


\section{Chlorogenic acid}

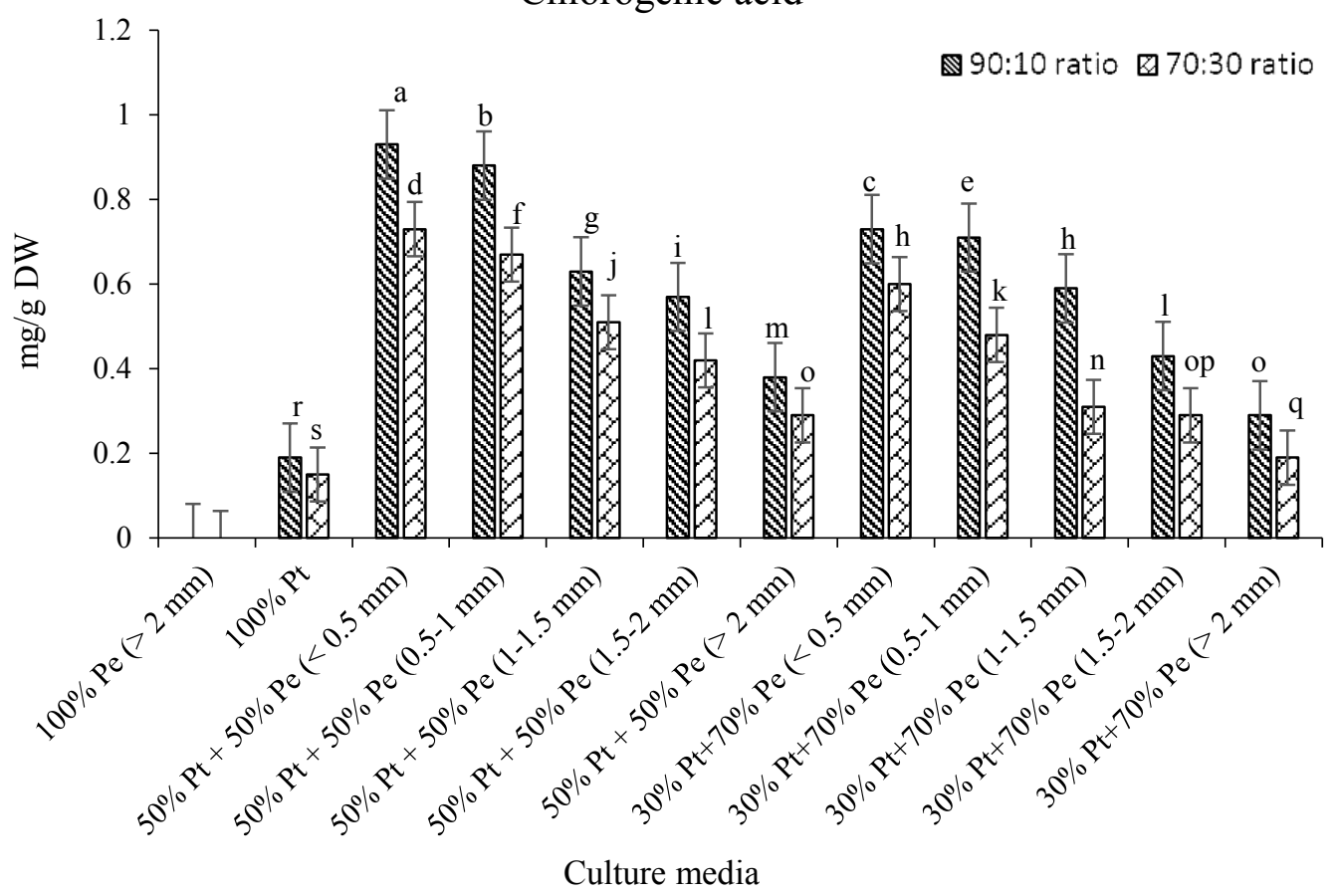

\section{Cynarin}



Culture media 


\section{Echinacoside}



Culture media

\section{Caftaric acid}

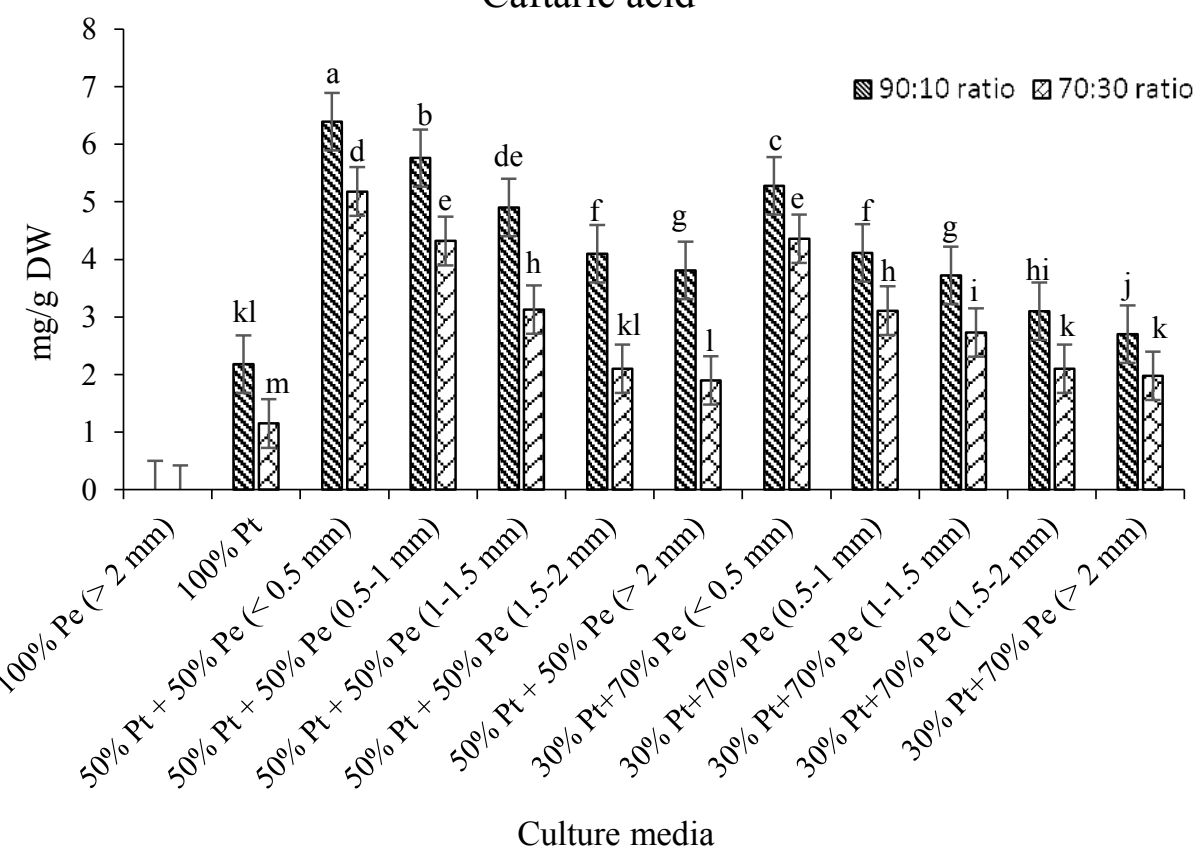






Fig. 4. Caffeic acid derivatives of E.purpurea root at different culture media and $\mathrm{NO}_{3}{ }^{-} / \mathrm{NH}_{4}{ }^{+}$ratios.

Both total phenolics and caffeic acid derivatives were affected by growing media and $\mathrm{NO}_{3}{ }^{-} / \mathrm{NH}_{4}{ }^{+}$ ratios. The highest root total phenolics (42 mg GAE/g DW) and concentrations of different caffeic acid deviations in all samples were found in cultivated E. purpurea at the $50 \%$ perlite $+50 \%$ peat mass medium with perlite particle size less than $0.5 \mathrm{~mm}$ and 90:10 $\mathrm{NO}_{3}{ }^{-} / \mathrm{NH}_{4}{ }^{+}$ratio (Figures 3 and 4). Total phenolic compounds (Figure 3) and caffeic acid derivatives (Figure 4) decreased with a decreasing $\mathrm{NO}_{3}{ }^{-} / \mathrm{NH}_{4}{ }^{+}$ratio. Meanwhile, increasing the particle size of perlite in culture media decreased the total phenolic compounds (Figure 3) and caffeic acid derivatives concentration (Figure 4) in the samples. In general, the dried E. purpurea root contained more chicoric acid ( $\max$ $17 \mathrm{mg} / \mathrm{g} \mathrm{DW}$ ) and caftaric acid (max $6.3 \mathrm{mg} / \mathrm{g}$ DW) than other compounds in all treatments (Figure 4). Many studies have shown that the formation and collection of phenolic compounds in various plant organs is a mechanism to cope with the stresses caused by overexploitation of plant nutrients 36. It is demonstrated that the biosynthesis of root phenolic compounds caused reduce in nitrate toxicity ${ }^{5}$. There are previous reports ${ }^{29}$ showing that the phenylalanine ammonia-lyase (PLA) activity was increased under stress conditions. The activity of PLA depends on the stage of plant growth $^{1}$. Meanwhile, plant growth conditions, time of harvest, and geographical location affect the PLA activity ${ }^{27}$. The same results were reported by Vidović et al (2019). The various secondary metabolites are responsible for medically active compounds under plant stress conditions ${ }^{40}$, which the synthesis, accumulation, sequestration, and degradation pathways have not been elucidated ${ }^{25}$.

Plants may produce large amounts of phenolic compounds and phenolic derivatives in the roots in response to exceed nitrate accumulation ${ }^{7}$. According to Ghabaei et al (2019), one of the mitigating mechanisms of nitrogen excess stress is the accumulation of phenolic compounds in the plant. Therefore, it can be said that creating stress conditions during plant growth conditions is one 
of the effective ways to increase the active compounds in the plants ${ }^{13}$. Chicoric acid, chlorogenic acid, caftaric acid, cynarin, and echinacoside are the most potential phenolic compounds in E.purpurea root extract ${ }^{40}$. Different culture media resulted in different concentrations of these caffeic acid derivatives (Figure 4). Overall, plants grown on the $50 \%$ perlite $+50 \%$ peat mass medium with perlite particle size less than $0.5 \mathrm{~mm}$ and $90: 10 \mathrm{NO}_{3}{ }^{-} / \mathrm{NH}_{4}{ }^{+}$ratio had the highest concentrations of chicoric acid $(17 \mathrm{mg} / \mathrm{g} \mathrm{DW})$, caftaric acid $(6.3 \mathrm{mg} / \mathrm{g} \mathrm{DW})$, chlorogenic acid $(0.93$ $\mathrm{mg} / \mathrm{g} \mathrm{DW})$, cynarin $(0.84 \mathrm{mg} / \mathrm{g} \mathrm{DW})$, and echinacoside $(0.73 \mathrm{mg} / \mathrm{g} \mathrm{DW})$. It found that the concentration of chicoric acid was more than other derivatives in all culture media, which significantly decreased by increasing perlite particle size and decreasing $\mathrm{NO}_{3}{ }^{-} / \mathrm{NH}_{4}{ }^{+}$ratios. The same trend was found for other derivatives (Figure 4). The difference in the phenolic acid concentrations extracted from the plant roots depends on various factors such as environmental growth conditions (light, temperature, and humidity) and especially the growing period of the plant 7. It is well known that the concentrations of caffeic acid derivatives is different during vegetative to reproductive stages ${ }^{19}$. According to Karg et al (2019), a significant increase in chicoric acid concentration was obtained at the end of the reproductive stage. However, the chlorogenic acid, echinacoside, and cynarin content were significantly reduced in the period ${ }^{25}$. Accordingly, the determination of caffeic acid deviations at the end of the flowering stage at the present study found more chicoric acid and caftaric acid concentrations than others. According to Lema-Rumińska et al (2019), the chicoric acid and caftaric acid concentrations in the plant root extract were 5.3 and $1.5 \mathrm{mg} / \mathrm{g} \mathrm{DW}$, respectively. In other research ${ }^{24}$, the concentrations of chicoric acid and caftaric acid in the root of E. purpurea extract were 8.3 and $2.2 \mathrm{mg} / \mathrm{g} \mathrm{DW}$, respectively. However, the chicoric acid and caftaric acid concentrations in the present study were found maximum 17 and $6.9 \mathrm{mg} / \mathrm{g}$ DW respectively at the $50 \%$ perlite $+50 \%$ peat mass medium with perlite particle size less than $0.5 \mathrm{~mm}$ and 90:10 $\mathrm{NO}_{3}{ }^{-} / \mathrm{NH}_{4}{ }^{+}$ratio, which indicates the influence of growing media and nutrition pattern on the plant phytochemical parameters.

The antiviral activity and protective effects of chicoric acid on the free radical-induced collagen degradation were reported ${ }^{22}$. The improving of immunity and antioxidant effects of E.purpurea is correlated with polyphenols compound such as caftaric acid. Among all caffeic acid derivatives, caftaric acid and chlorogenic acid can act an extreme antioxidants against free radicals ${ }^{39}$. Echinacoside and caffeic acid have antiviral and antibacterial effects against reactive oxygen species ${ }^{38}$. According to the results, the maximum echinacoside and cynarin concentrations of E. purpurea root extract were significantly more than previous reports ${ }^{10,21}$. Increasing echinacoside concentration, as an effective phytochemical compound and secondary metabolite of E. purpurea is so important in Pharmacognosy and herbal researches ${ }^{7}$. It was found that echinacoside could prevent the progress of neurodegeneration in Parkinson's and Alzheimer's diseases $^{38}$. 
Alkylamides. High performance liquid chromatography investigation of the alkylamide constituents revealed the presence of 11 alkylamides in the E. purpurea root extract (Table 2); however, the percentage of the alkylamides are widely different in the plants grown on different culture media and $\mathrm{NO}_{3}{ }^{-} / \mathrm{NH}_{4}{ }^{+}$ratios (Tables 3 and 4).

\begin{tabular}{|l|l|l|}
\hline Compound & Rt $^{*}$ & Constituents \\
\hline & $(\mathrm{min})$ & \\
\hline 1 & 13.38 & Undeca, 2E,4Z-diene-8,10-diynoic acid isobutylamide \\
\hline 2 & 15.73 & Undeca, 2Z,4E-diene-8,10-diynoic acid isobutylamide \\
\hline 3 & 16.25 & Dodeca-2E, 4Z- diene-8,10-diynoic acid isobutylamide \\
\hline 4 & 17.92 & Dodeca-2E, 4Z- diene-8,10-diynoic acid 2-methylbutylamide \\
\hline 5 & 19.35 & Dodeca-4E, 10E-trien-8,10- diynoic acid 2-methylbutylamide \\
\hline 6 & 20.09 & Trideca, 2E, 7Z-diene-10, 12- diynoic acid isobutylamide \\
\hline 7 & 20.80 & Dodeca-2E, 4Z- diene-8,10-diynoic acid 2-methylbutylamide \\
\hline 8 & 23.90 & Dodeca-2E, 4E, 8Z- 10 (E/Z)-tetraenoic acid isobutylamide \\
\hline 9 & 24.10 & Dodeca-2E, 4E, 8Z,10 (E/Z)-tetraenoic acid isobutylamide \\
\hline 10 & 28.61 & Dodeca-2E, 4E, 8Z- tetraenoic acid isobutylamide \\
\hline 11 & 30.35 & Dodeca-2E, 4E- dienoic acid isobutylamide \\
\hline
\end{tabular}

*Retention time in HPLC system

Table 2. Alkylamide composition of E. purpurea.

The highest percentage of different alkylamides were found in the E. purpurea grown at 50:50 v/v perlite to peat moss ratio culture media. The E. purpurea grown at the culture media with higher perlite volume percentage, had the lowest alkylamides percentages, as the lowest percentage (not detectable) of alkylamides was found in the plants grown in $100 \%$ perlite culture medium. Perlite particle size also affected the alkylamides percentages. Increasing the perlite particle size in culture media, leads to a decrease in the E. purpurea root alkylamides percentages. The culture media with perlite particle size less than $0.5 \mathrm{~mm}$ had more alkylamides percentages than others. More alkylamides percentage were found in the $E$. purpurea root extract by increasing of $\mathrm{NO}_{3}{ }^{-} / \mathrm{NH}_{4}{ }^{+}$ratio (Tables 3 and 4). 


\begin{tabular}{|c|c|c|c|c|c|c|c|c|c|c|c|}
\hline \multirow[b]{2}{*}{ Culture media } & \multicolumn{11}{|c|}{ Alkylamides (\% of total dry weight) } \\
\hline & 1 & 2 & 3 & 4 & 5 & 6 & 7 & 8 & 9 & 10 & 11 \\
\hline $100 \% \mathrm{Pe}(>2 \mathrm{~mm})$ & $\mathrm{nd}^{*}$ & nd & nd & nd & nd & nd & nd & nd & nd & nd & nd \\
\hline $100 \% \mathrm{Pt}$ & 2.25 & 1.42 & 1.22 & trace & 0.81 & 13.68 & trace & 45.91 & 30.1 & 1.10 & 0.66 \\
\hline $50 \% \mathrm{Pt}+50 \% \mathrm{Pe}(<0.5 \mathrm{~mm})$ & 0.81 & trace & 0.25 & trace & 0.10 & trace & 2.11 & 54.21 & 39.19 & 2.33 & 1 \\
\hline $50 \% \mathrm{Pt}+50 \% \mathrm{Pe}(0.5-1 \mathrm{~mm})$ & 4.32 & 0.74 & trace & 0.15 & 2.35 & 3 & 1.65 & 50.09 & 35.21 & 1.58 & 0.91 \\
\hline $50 \% \mathrm{Pt}+50 \% \mathrm{Pe}(1-1.5 \mathrm{~mm})$ & 5.96 & 0.71 & 2.19 & 3.69 & trace & 2.17 & 1.29 & 48.69 & 33.12 & 1.35 & 0.83 \\
\hline $50 \% \mathrm{Pt}+50 \% \mathrm{Pe}(1.5-2 \mathrm{~mm})$ & 9.09 & 0.68 & 1.51 & 2.67 & 1.09 & 1.91 & 1.19 & 47 & 32.95 & 1.11 & 0.80 \\
\hline $50 \% \mathrm{Pt}+50 \% \mathrm{Pe}(>2 \mathrm{~mm})$ & 15.96 & 0.66 & 0.84 & trace & trace & 1.63 & 0.92 & 46.19 & 32.11 & 0.96 & 0.73 \\
\hline $30 \% \mathrm{Pt}+70 \% \mathrm{Pe}(<0.5 \mathrm{~mm})$ & 2 & 1.32 & trace & 2.19 & trace & 1.16 & 1.90 & 52.16 & 36.38 & 1.96 & 0.93 \\
\hline $30 \% \mathrm{Pt}+70 \% \mathrm{Pe}(0.5-1 \mathrm{~mm})$ & 9.7 & 1.15 & 0.81 & 2.11 & 0.94 & trace & 0.87 & 49.03 & 33.29 & 1.40 & 0.70 \\
\hline $30 \% \mathrm{Pt}+70 \% \mathrm{Pe}(1-1.5 \mathrm{~mm})$ & 16.63 & 0.92 & 0.77 & trace & trace & 0.98 & 0.83 & 46.20 & 31.69 & 1.32 & 0.66 \\
\hline $30 \% \mathrm{Pt}+70 \% \mathrm{Pe}(1.5-2 \mathrm{~mm})$ & 18.06 & trace & 0.60 & 1.13 & 0.89 & 0.71 & 0.72 & 45.65 & 30.59 & 1.05 & 0.60 \\
\hline $30 \% \mathrm{Pt}+70 \% \mathrm{Pe}(>2 \mathrm{~mm})$ & 22.79 & 0.63 & trace & trace & 0.83 & 0.66 & 0.59 & 43.19 & 30.10 & 0.67 & 0.54 \\
\hline
\end{tabular}

Table 3. Alkylamides percentage of $E$. purpurea grown at different culture media and 90:10 $\mathrm{NO}_{3}{ }^{-} / \mathrm{NH}_{4}{ }^{+}$ratio

\begin{tabular}{|c|c|c|c|c|c|c|c|c|c|c|c|}
\hline \multirow[b]{2}{*}{ Culture media } & \multicolumn{11}{|c|}{ Alkylamides ( $\%$ of total dry weight) } \\
\hline & 1 & 2 & 3 & 4 & 5 & 6 & 7 & 8 & 9 & 10 & 11 \\
\hline $100 \% \mathrm{Pe}(>2 \mathrm{~mm})$ & nd & nd & nd & nd & nd & nd & nd & nd & nd & nd & nd \\
\hline $100 \% \mathrm{Pt}$ & 18.33 & 1.20 & 0.98 & trace & 0.63 & 12.30 & trace & 39.39 & 25.69 & 0.91 & 0.57 \\
\hline $50 \% \mathrm{Pt}+50 \% \mathrm{Pe}(<0.5 \mathrm{~mm})$ & 21.03 & trace & 0.27 & trace & trace & trace & 1.32 & 43.58 & 31.69 & 1.38 & 0.73 \\
\hline $50 \% \mathrm{Pt}+50 \% \mathrm{Pe}(0.5-1 \mathrm{~mm})$ & 23.99 & 0.62 & trace & 0.13 & 1.62 & 2.46 & 1.10 & 40.36 & 27.61 & 1.49 & 0.62 \\
\hline $50 \% \mathrm{Pt}+50 \% \mathrm{Pe}(1-1.5 \mathrm{~mm})$ & 31.75 & 0.73 & 1.35 & 2.51 & trace & 1.98 & 0.94 & 34.69 & 24.39 & 1.09 & 0.57 \\
\hline $50 \% \mathrm{Pt}+50 \% \mathrm{Pe}(1.5-2 \mathrm{~mm})$ & 37.18 & 0.54 & 1.09 & 1.16 & 0.84 & 1.14 & 0.84 & 32.10 & 23.84 & 0.87 & 0.43 \\
\hline $50 \% \mathrm{Pt}+50 \% \mathrm{Pe}(>2 \mathrm{~mm})$ & 39.39 & 0.48 & 0.76 & trace & trace & 0.94 & 0.62 & 31.69 & 25.10 & 0.62 & 0.40 \\
\hline $30 \% \mathrm{Pt}+70 \% \mathrm{Pe}(<0.5 \mathrm{~mm})$ & 24.09 & 1.18 & trace & 1.59 & trace & 0.91 & 0.91 & 42.18 & 27.39 & 1.14 & 0.61 \\
\hline $30 \% \mathrm{Pt}+70 \% \mathrm{Pe}(0.5-1 \mathrm{~mm})$ & 31 & 1.01 & 0.71 & 1.13 & 0.72 & trace & 0.74 & 37.39 & 25.97 & 0.91 & 0.42 \\
\hline $30 \% \mathrm{Pt}+70 \% \mathrm{Pe}(1-1.5 \mathrm{~mm})$ & 39.25 & 0.81 & 0.69 & trace & trace & 0.72 & 0.63 & 35.40 & 21.39 & 0.72 & 0.39 \\
\hline $30 \% \mathrm{Pt}+70 \% \mathrm{Pe}(1.5-2 \mathrm{~mm})$ & 43.37 & trace & 0.60 & 0.94 & 0.62 & 0.68 & 0.53 & 31.96 & 20.39 & 0.66 & 0.25 \\
\hline $30 \% \mathrm{Pt}+70 \% \mathrm{Pe}(>2 \mathrm{~mm})$ & 45.93 & 0.59 & trace & trace & 0.48 & 0.53 & 0.49 & 31.12 & 20.09 & 0.58 & 0.19 \\
\hline
\end{tabular}

Table 4. Alkylamides percentage of E. purpurea grown at different culture media and 70:30 $\mathrm{NO}_{3}{ }^{-} / \mathrm{NH}_{4}{ }^{+}$ratio.

"nd: not detected (very low percentage) 
The major alkylamide in the E. purpurea root extract was dodeca-2E, 4E, 8Z- 10 (E/Z)tetraenoic acid isobutylamide (isomeric compounds labeled with 8 and 9 in Table 3) in all treatments, ranging from 31.12 to $54.21 \%$ of total dry weight, which was varied at different culture media and $\mathrm{NO}_{3}{ }^{-} / \mathrm{NH}_{4}{ }^{+}$ratios. The alkylamide percentage was the highest $(54.21 \%)$ of all at the 50:50 v/v perlite to peat moss ratio with perlite particle size less than $0.5 \mathrm{~mm}$ and $90: 10 \mathrm{NO}_{3}{ }^{-} / \mathrm{NH}_{4}{ }^{+}$ ratio. Decreasing of perlite volume percentage and particle size caused to increase of the alkylamide percentage in E. purpurea root extract (Tables 3 and 4). In contrast, it was found that the undeca, 2E, 4Z-diene-8, 10-diynoic acid isobutylamide (compound label with 1 in Table 3) had different trend against of other alkylamides, which increased by increasing of perlite volume percentage, particle size, and $\mathrm{NO}_{3}{ }^{-} / \mathrm{NH}_{4}{ }^{+}$ratio (Tables 3 and 4).

Several isomeric pairs of alkylamides found in Echinacea, the structures differing solely by the double-bond configuration ${ }^{17}$. Stuart and Wills (2000) showed that the E. purpurea root extract contained $70 \%$ of the total plant alkylamides with $20 \%$ in flower, and $10 \%$ in the stem. They also reported that the dodeca-2E, 4E, 8Z- 10 (E/Z)-tetraenoic acid isobutylamide was the main alkylamide in the root extract (32.73\% of total dry weight). More than 20 different alkylamides were identified based on their mass spectra in the E. purpurea root extract by the LC-MS method ${ }^{26}$. They reported that the total percentage of the dodeca-2E, 4E, 8Z- 10 (E/Z)-tetraenoic acid isobutylamide was $36.81 \%$. Based on the fact that the phytochemical profiles of different Echinacea products are highly variable and strictly depend on the plant growth stage, Gulledge et al (2018) reported that the higher percentage of root alkylamides, especially dodeca-2E, 4E, 8Z10 (E/Z)-tetraenoic acid isobutylamide (30.69\%) was found at the flowering stage. Comparing of results of the present study with different previous reports showed the higher percentage of root alkylamides in E. purpurea growing at the $50: 50 \mathrm{v} / \mathrm{v}$ perlite to peat moss ratio with perlite particle size less than $0.5 \mathrm{~mm}$ at $90: 10 \mathrm{NO}_{3}{ }^{-} / \mathrm{NH}_{4}{ }^{+}$ratio. The percentage of dodeca-2E, $4 \mathrm{E}, 8 \mathrm{Z}-10(\mathrm{E} / \mathrm{Z})-$ tetraenoic acid isobutylamide in this study was more than that reported by other researchers (Tables 3 and 4). Dodeca-2E, 4E, 8Z- 10 (E/Z)-tetraenoic acid isobutylamide has been shown to induce anti-inflammatory responses in mouse macrophages ${ }^{11}$ interact with the endocannabinoid system ${ }^{15}$ and inhibit COX-2 activity ${ }^{28}$ confirming the in vitro effect of this compound on the immune response.

Conclusion. In summary, the results demonstrate that hydroponic cultivation of E. purpurea at different volume percentages of perlite and peat moss with application of different $\mathrm{NO}_{3}{ }^{-} / \mathrm{NH}_{4}{ }^{+}$ ratios could affect the phytochemical properties of the plant. Decreasing perlite size and increase of $\mathrm{NO}_{3}{ }^{-} \mathrm{NH}_{4}{ }^{+}$ratio caused a significant increase in total phenolic content and different caffeic acid derivatives concentrations, including chicoric acid, caftaric acid, chlorogenic acid, cynarin, and echinacoside, as well as different alkylamides percentage in E. purpurea root extract. The highest concentrations of caffeic acid derivatives and alkylamides percentage found in the medium containing very fine-grade perlite $(<0.5 \mathrm{~mm})$ with $50: 50 \mathrm{v} / \mathrm{v}$ perlite to peat moss ratio. The percentages of these phytochemical compounds were increased by increasing of $\mathrm{NO}_{3}{ }^{-} / \mathrm{NH}_{4}{ }^{+}$ratio. Dodeca-2E, 4E, 8Z- 10 (E/Z)-tetraenoic acid isobutylamide was the most predominant alkylamide 
in the plant root extract. Using perlite and peat moss mixture for plant cultivation not only affects the plant phytochemical compounds, but also reduces production costs in hydroponic systems.

\section{Acknowledgment}

The authors are thankful to Mr. Yahya Hasirchi for preparing experimental facilities and the Office of Vice Chancellor for Research and Technology, Urmia University.

\section{Funding}

This research did not receive any specific grant from funding agencies in the public, commercial, or not-for-profit sectors.

\section{Declarations of interest}

The authors declare that they have no conflict of interest.

\section{References}

1. Açikgöz, M. A., Yarılgaç, T., Kara, Ş. M. 2018. Enhancement of Phytochemical Compounds Using Biotic and Abiotic Elicitors in Purple Coneflower (Echinacea purpurea L.). Indian J Pharm Educ, 52 (1), 140-145.

2. Ahmadi, F., Samadi, A., Rahimi, A. 2020. Improving Growth Properties and Phytochemical Compounds of Echinacea purpurea (L.) Medicinal Plant Using Novel Nitrogen Slow Release Fertilizer under Greenhouse Conditions. Sci. Rep, 10 (1), 1-11.

3. Ahmadi, F., Samadi, A., Sepehr, E., Rahimi, A., Shabala, S. (2021). Perlite particle size and $\mathrm{NO}_{3}{ }^{-} / \mathrm{NH}_{4}{ }^{+}$ratio affect growth and chemical composition of purple coneflower (Echinacea purpurea L.) in hydroponics. Industrial Crops and Products, 161 (2), 113285.

4. Aiello, N., Marengo, A., Scartezzini, F., Fusani, P., Sgorbini, B., Rubiolo, P., Cagliero, C. 2020. Evaluation of the Farming Potential of Echinacea Angustifolia DC. Accessions Grown in Italy by Root-Marker Compound Content and Morphological Trait Analyses. Plants, 9 (7), 873- 880.

5. Alexandra, Z., Irina, M., Olga, B., Svetlana, N., Tatyana, K., Dina, P., Andrey, L. 2019. Quantitative and Qualitative Profile of Biologically Active Substances Extracted from Purple Echinacea (Echinacea purpurea L.) Growing in the Kemerovo region: Functional Foods Application. Foods raw mater, 7(1), 112-123.

6. Attarzadeh, M., Balouchi, H., Rajaie, M., Dehnavi, M. M., Salehi, A. 2020. Improving Growth and Phenolic Compounds of Echinacea purpurea Root by Integrating Biological and Chemical Resources of Phosphorus under Water Deficit Stress. Ind Crops Prod, 154 (1), 152-163.

7. Bai, Y., Ma, J., Zhu, W., Wang, L., Qu, W., Su, S., Zhang, J. 2019. Highly Selective Separation and Purification of Chicoric Acid from Echinacea purpurea by Quality Control Methods in Macroporous Adsorption Resin Column Chromatography. J. Sep. Sci, 42 (5), 1027-1036.

8. Balciunaite, G., Haimi, P. J., Mikniene, Z., Savickas, G., Ragazinskiene, O., Juodziukyniene, N., Pangonyte, D. 2020. Identification of Echinacea purpurea (L.) Moench root LysM Lectin with Nephrotoxic Properties. Toxins, 12 (2), 88-95.

9. Banica, F., Bungau, S., Tit, D. M., Behl, T., Otrisal, P., Nechifor, A. C., Nemeth, S. 2020. Determination of the Total Polyphenols Content and Antioxidant Activity of Echinacea Purpurea 
Extracts Using Newly Manufactured Glassy Carbon Electrodes Modified with Carbon Nanotubes. Processes, 8 (7), 833-840.

10. Bergeron, C., Gafner, S., Batcha, L. L., Angerhofer, C. K. (2002). Stabilization of caffeic acid derivatives in Echinacea purpurea L. glycerin extract. Journal of Agricultural and Food Chemistry, 50(14), 3967-3970.

11. Cheng, Z. Y., Sun, X., Liu, P., Lin, B., Li, L. Z., Yao, G. D., Song, S. J. 2020. Sesquiterpenes from Echinacea purpurea and Their Anti-inflammatory Activities. Phytochemistry, 179 (1), 115121.

12. Coelho, J., Barros, L., Dias, M. I., Finimundy, T. C., Amaral, J. S., Alves, M. J., Ferreira, I. C. 2020. Echinacea purpurea (L.) Moench: Chemical Characterization and Bioactivity of Its Extracts and Fractions. Pharmaceuticals, 13 (6), 125-132.

13. Demirci, T., Akçay, U. Ç., Baydar, N. G. 2020. Effects of 24-epibrassinolide and L-phenylalanine on Growth and Caffeic Acid Derivative Production in Hairy Root Culture of Echinacea purpurea L. Moench. Acta Physiol. Plant, 42 (5), 66-72.

14. Daley, E. 2019. A Phytochemical and Antibacterial Analysis of Echinacea purpurea (L.) Moench throughout Seasonal Development (Doctoral dissertation, Université d'Ottawa/University of Ottawa).

15. Elufioye, T. O., Habtemariam, S., Adejare, A. (2020). Chemistry and Pharmacology of Alkylamides from Natural Origin. Revista Brasileira de Farmacognosia, 1-19.

16. Ghabaei, T., Nazirzadeh, S., Nourafcan, H. 2019. Effect of Different Drying Methods on Quantity and Quality of Active Substances of Purple Coneflower (Echinacea purpurea L.). J. Med. Herb, 9 (3), 115-120.

17. Gulledge, T. V., Collette, N. M., Mackey, E., Johnstone, S. E., Moazami, Y., Todd, D. A., Laster, S. M. (2018). Mast cell degranulation and calcium influx are inhibited by an Echinacea purpurea extract and the alkylamide dodeca-2E, 4E-dienoic acid isobutylamide. Journal of ethnopharmacology, 212, 166-174.

18. Jain, R. S., Dhangar, K. B., Jaiswal, H. P., Shaikh, A. Z. 2020. Review on Echinacea and its Species. Asian J. Pharm. Sci, 10 (3), 226-235.

19. Karg, C. A., Wang, P., Vollmar, A. M., Moser, S. 2019. Re-opening the Stage for Echinacea Research-Characterization of Phylloxanthobilins as a Novel Anti-oxidative Compound Class in Echinacea purpurea. Phytomedicine, 4 (2), 152-160.

20. Lema-Rumińska, J., Kulus, D., Tymoszuk, A., Varejão, J. M., Bahcevandziev, K. 2019. Profile of Secondary Metabolites and Genetic Stability Analysis in New Lines of Echinacea purpurea (L.) Moench Micropropagated via Somatic Embryogenesis. Ind Crops Prod, 142 (1), 115-122.

21. Liu, C. Z., Abbasi, B. H., Gao, M., Murch, S. J., Saxena, P. K. (2006). Caffeic acid derivatives production by hairy root cultures of Echinacea purpurea. Journal of agricultural and food chemistry, 54(22), 8456-8460. 
22. Maggini, V., De Leo, M., Granchi, C., Tuccinardi, T., Mengoni, A., Gallo, E. R., Bogani, P. 2019. The Influence of Echinacea purpurea Leaf Microbiota on Chicoric Acid Level. Sci. Rep, 9 (1), 1-11.

23. Matthias, A., Blanchfield, J. T., Penman, K. G., Toth, I., Lang, C. S., De Voss, J. J., Lehmann, R. P. (2004). Permeability studies of alkylamides and caffeic acid conjugates from echinacea using a Caco-2 cell monolayer model. Journal of Clinical Pharmacy and Therapeutics, 29(1), 7-13.

24. Mei, B., Xie, H., Xing, H., Kong, D., Pan, X., Li, Y., Wu, H. 2020. Changes of Phenolic Acids and Antioxidant Activities in Diploid and Tetraploid Echinacea purpurea at Different Growth Stages. Rev Bras Farmacogn, 30 (4), 510-518.

25. Momchev, P., Ciganović, P., Jug, M., Marguí, E., Jablan, J., Zovko Končić, M. 2020. Comparison of Maceration and Ultrasonication for Green Extraction of Phenolic Acids from Echinacea purpurea Aerial Parts. Molecules, 25 (21), 142-150.

26. Mudge, E., Lopes-Lutz, D., Brown, P., Schieber, A. (2011). Analysis of alkylamides in Echinacea plant materials and dietary supplements by ultrafast liquid chromatography with diode array and mass spectrometric detection. Journal of agricultural and food chemistry, 59(15), 80868094.

27. Oniszczuk, T., Oniszczuk, A., Gondek, E., Guz, L., Puk, K., Kocira, A., Wójtowicz, A. 2019. Active Polyphenolic Compounds, Nutrient Contents and Antioxidant Capacity of Extruded Fish Feed Containing Purple Coneflower (Echinacea purpurea (L.) Moench.). Saudi J. Biol. Sci, 26 (1), 24-30.

28. Oláh, A., Szabó-Papp, J., Soeberdt, M., Knie, U., Dähnhardt-Pfeiffer, S., Abels, C., Bíró, T. (2017). Echinacea purpurea-derived alkylamides exhibit potent anti-inflammatory effects and alleviate clinical symptoms of atopic eczema. Journal of dermatological science, 88(1), 67-77.

29. Parsons, J. L., Liu, R., Smith, M. L., Harris, C. S. 2018. Echinacea Fruit: Phytochemical Localization and Germination in Four Species of Echinacea. Botany, 96 (7), 461-470.

30. Ramezannezhad, R., Aghdasi, M., Fatemi, M. 2019. Enhanced Production of Chicoric Acid in Cell Suspension Culture of Echinacea purpurea by Silver Nanoparticle Elicitation. Plant Cell, Tissue Organ Cult.139 (2), 261-273.

31. Samadi, A., 2011. Effect of the Particle Size Distribution of Perlite and Its Mixture with Organic Substrates on Cucumber in the Hydroponics System. J. Agric. Sci. Technol. 13 (1), 121129.

32. Senica, M., Mlinsek, G., Veberic, R., Mikulic-Petkovsek, M. 2019. Which Plant Part of Purple Coneflower (Echinacea purpurea (L.) Moench) Should be Used for Tea and Which for Tincture?. J. Med. Food, 22 (1), 102-108.

33. Singleton, V.L., Orthofer, R., Lamuela-Raventós, R.M. 1999. Analysis of total phenols and other oxidation substrates and antioxidants by means of folin-ciocalteu reagent. Methods Enzymol. 299, 152-178.

34. Stuart, D. L., Wills, R. B. H. (2000). Alkylamide and cichoric acid levels in Echinacea purpurea tissues during plant growth. Journal of herbs, spices \& medicinal plants, 7(1), 91-101. 
35. Tajner-Czopek, A., Gertchen, M., Rytel, E., Kita, A., Kucharska, A. Z., Sokół-Łętowska, A. 2020. Study of Antioxidant Activity of Some Medicinal Plants Having High Content of Caffeic Acid Derivatives. Antioxidants, 9 (5), 412-419.

36. Vidović, S., Nastić, N., Gavarić, A., Cindrić, M., Vladić, J. 2019. Development of Green Extraction Process to Produce Antioxidant-rich Extracts from Purple Coneflower. Sep Sci Technol, 54 (7), 1174-1181.

37. Waidyanatha, S., Pierfelice, J., Cristy, T., Mutlu, E., Burback, B., Rider, C. V., Ryan, K. 2020. A Strategy for Test Article Selection and Phytochemical Characterization of Echinacea purpurea Extract for Safety Testing. Food Chem. Toxicol, 4 (1), 111-119.

38. Zaushintsena, A. V., Milentyeva, I. S., Babich, O. O., Kiseleva, T. F., Popova, D. G., Bakin, I. A., Lukin, A. A. 2019. Quantitative and Qualitative Profile of Biologically Active Substances Extracted from Purple Echinacea (Echinacea Purpurea L.) Growing in the Kemerovo Region: Functional Foods Application. Foods raw mater, 7 (1), 152-161.

39. Zazharskyi, V. V., Davydenko, P., Kulishenko, O., Borovik, I. V., Brygadyrenko, V. V. 2019. Antimicrobial Activity of 50 Plant Extracts. Biosyst. Divers, 27 (2), 223-230.

40. Zheng, Y., Dixon, M., Saxena, P., 2006. Greenhouse production of Echinacea purpurea (L.) and $E$. angustifolia using different growing media, $\mathrm{NO}_{3}{ }^{-} / \mathrm{NH}_{4}{ }^{+}$ratios, and watering regimes. Can. J. Plant Sci. 86 (3), 809-815. 


\section{Figures}
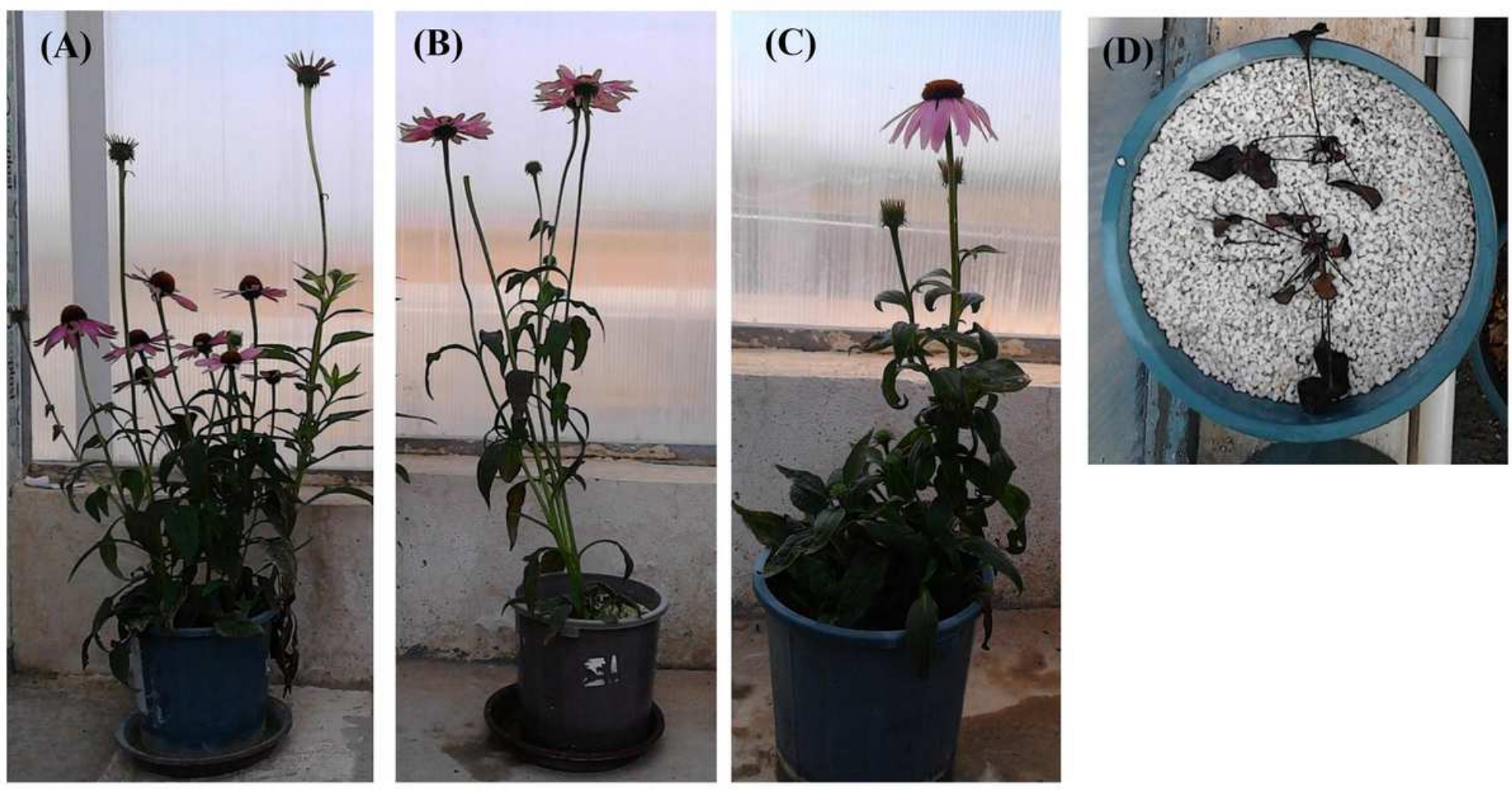

Figure 1

Please see the Manuscript PDF file for the complete figure caption

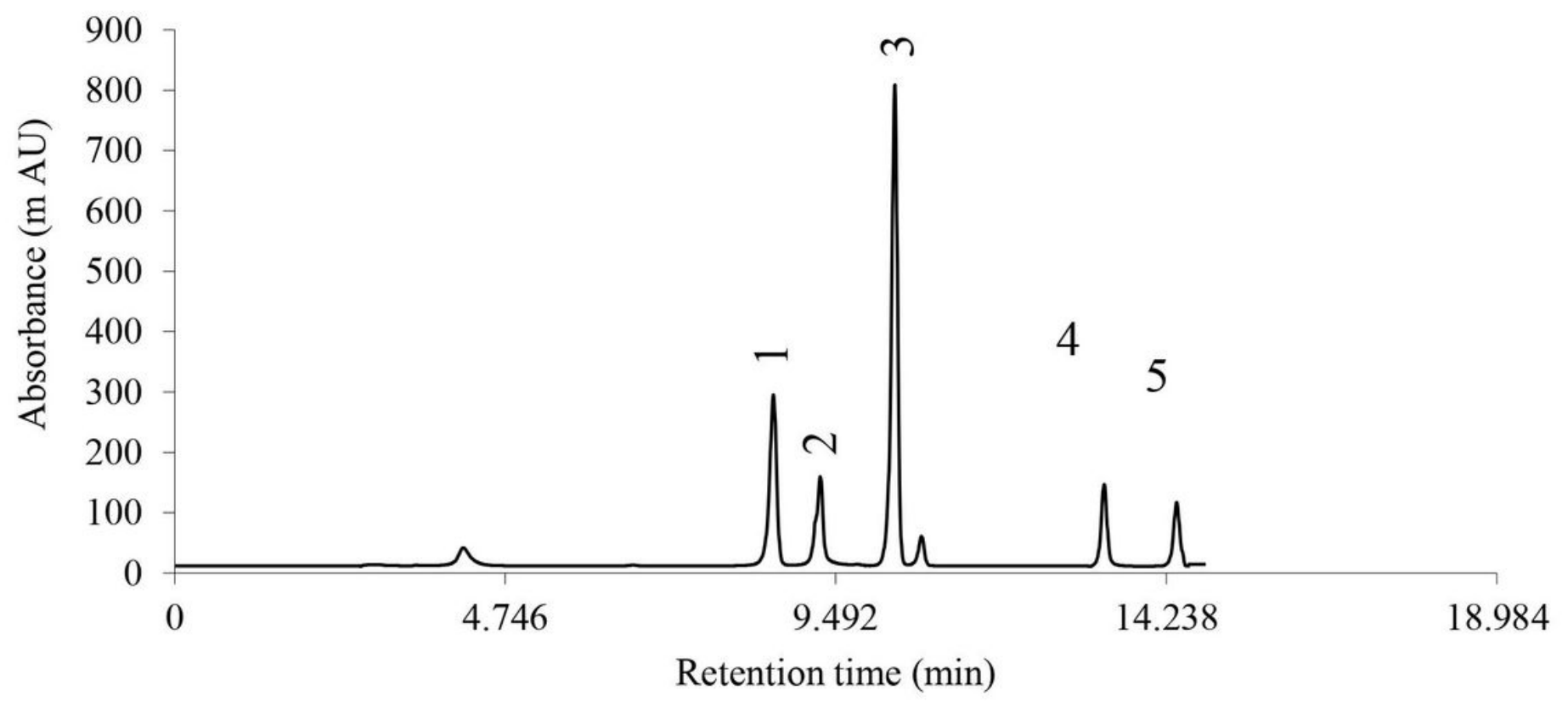

Figure 2

Please see the Manuscript PDF file for the complete figure caption 


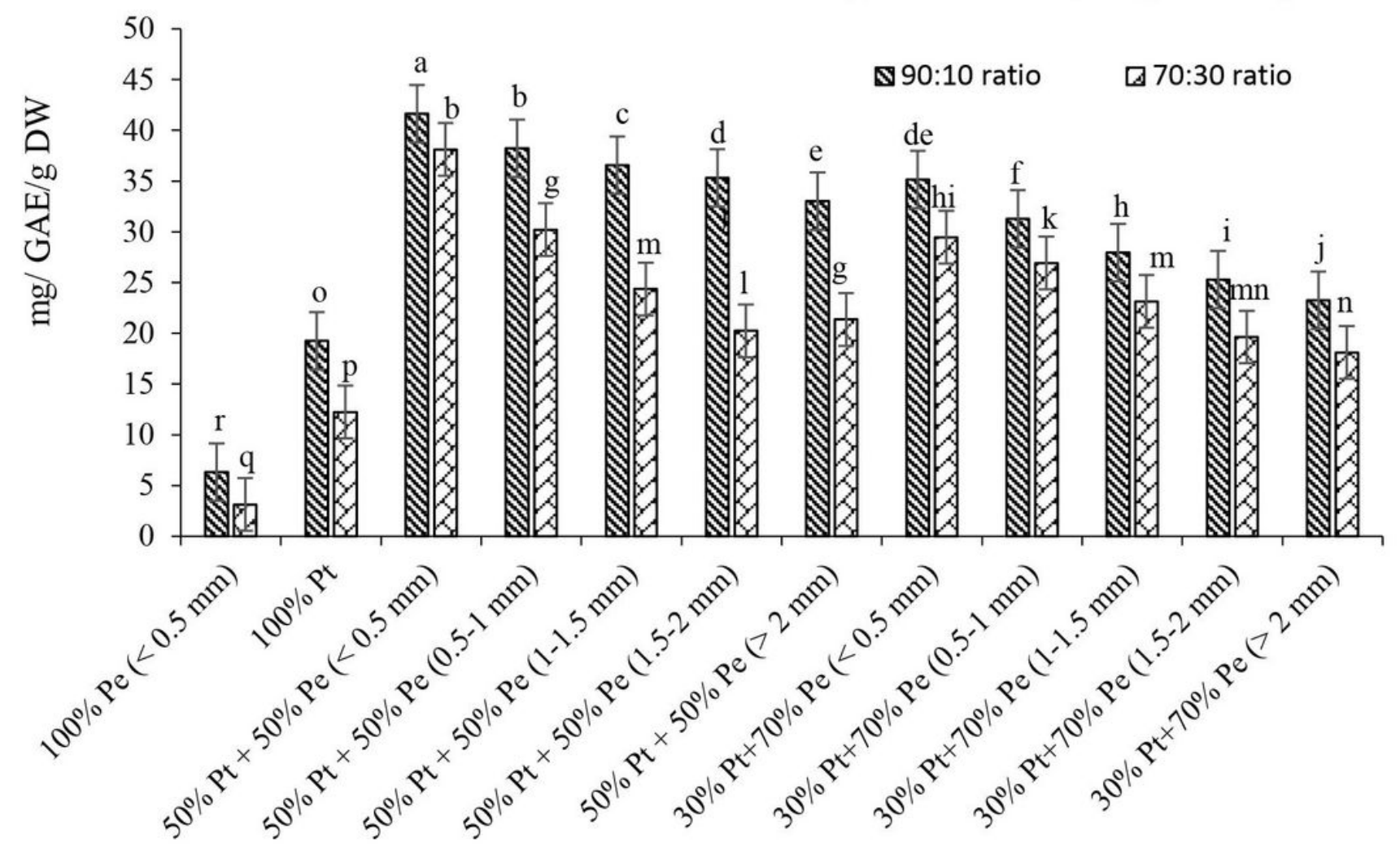

Culture media

Figure 3

Please see the Manuscript PDF file for the complete figure caption 

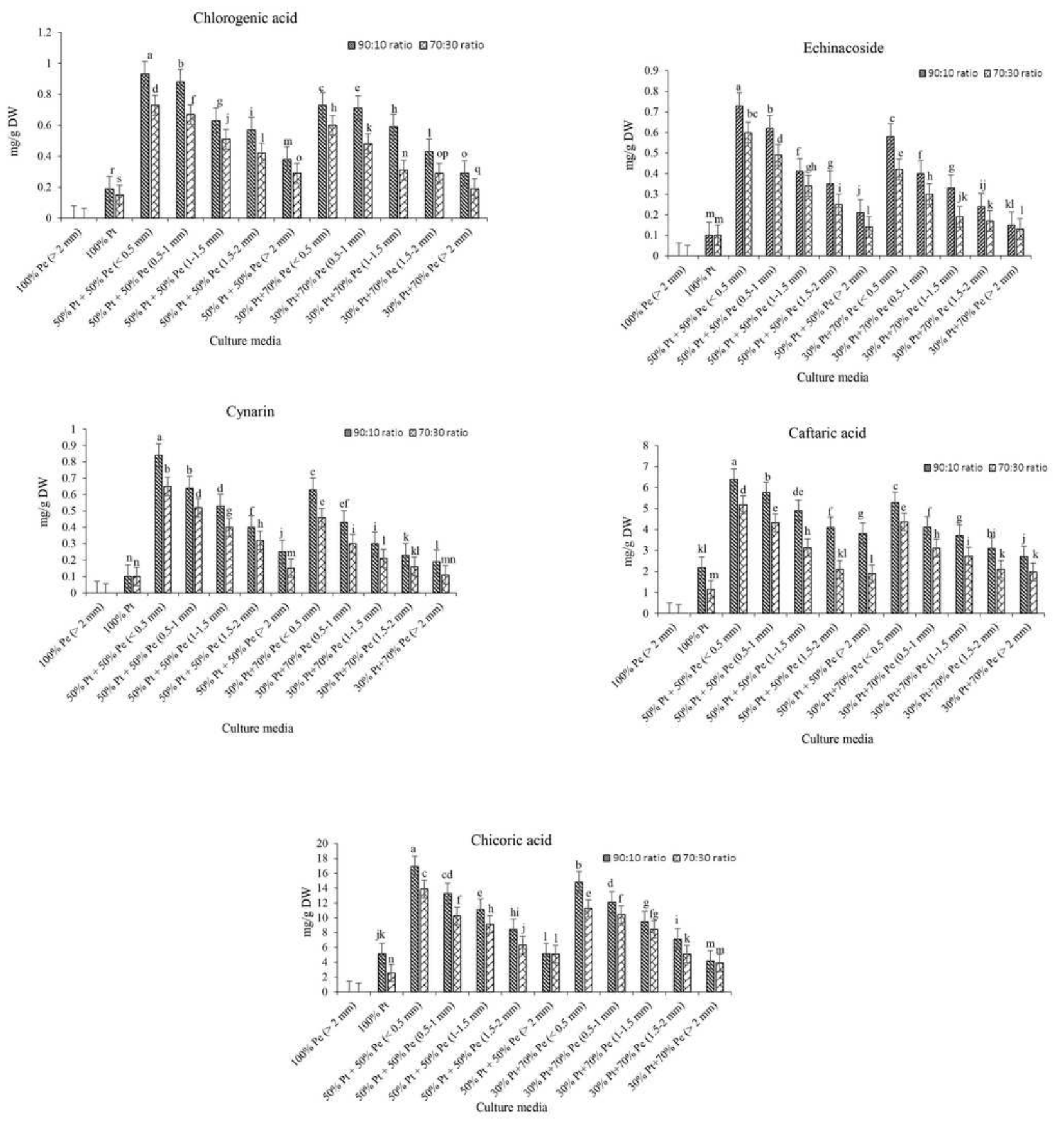

Figure 4

Please see the Manuscript PDF file for the complete figure caption 